\title{
Assessing the Influence of Inter Tropical Discontinuity on Total Column Ozone Variation Over West Africa
}

Ayomide Victor Arowolo ( $\square$ vaarowolo@gmail.com )

Federal University of Technology Akure School of Earth and Mineral Sciences https://orcid.org/00000001-7881-7043

\section{Ayodeji Oluleye}

Federal University of Technology Akure

\section{Research Article}

Keywords: Total column ozone, Inter-tropical discontinuity, Mann-Kendall, West Africa

Posted Date: December 8th, 2021

DOl: https://doi.org/10.21203/rs.3.rs-1037029/v1

License: (c) (1) This work is licensed under a Creative Commons Attribution 4.0 International License.

Read Full License 


\section{ASSESSING THE INFLUENCE OF INTER TROPICAL DISCONTINUITY ON TOTAL COLUMN OZONE \\ 2 VARIATION OVER WEST AFRICA}

3 Ayomide Victor Arowolo ${ }^{1^{*}}$ and Ayodeji Oluleye ${ }^{1}$

$4{ }^{1}$ Department of Meteorology and Climate Science, Federal University of Technology, Akure, Nigeria.

5 Corresponding Author: Ayomide Arowolo

6 Email: vaarowolo@gmail.com

7 ABSTRACT

8 The focus of this study is to evaluate the influence of Intertropical Discontinuity (ITD) on the variation of

9 Total column ozone (TCO). Relevant information is supplied on the temporal and spatial variability of TCO

10 along the ITD zone, which is an important factor influencing the earth's atmosphere. Several studies over

11 the years have established the relationship and influence several atmospheric processes have on TCO.

12 However, the relationship between Intertropical discontinuity and TCO over West Africa has a gap. This

13 study tends to examine the influence ITD has on TCO variation using the West Africa region as a case

14 study. The study used Wind, ozone and dewpoint temperature data for the period between 1980-2019.

15 To assess the variability and trend over the study region, several statistical methods were used, including

16 Pearson correlation, Mann-Kendall, and linear regression model. The Mann-Kendall test shows an

17 increasing trend throughout the months over the study region. Spatial analysis also revealed that regions

18 North of the ITD has a higher concentration of TCO that the southern region of the ITD. however, ITD

19 influence was more visible during the wet month of June to August (JJA) as the highest concentration of

20 TCO was observed during this period across all latitude but more deviation was observed between latitude

$2110^{\circ} \mathrm{N}$ to $18^{\circ} \mathrm{N}$, while the least occurrence is observed when ITD is at its minimum position in the month of

22 December to February (DJF). The ACRV shows that $14^{\circ} \mathrm{N}$ exhibit the highest variation with a value of 4.84 ,

23 while the deviation is also at its highest with value of 13.65. The monthly position of ITD for Forty years

24 was also analysed to observe the monthly deviation along the ITD region forty years and the spatial

25 distribution of TCO was analysed from January to December. It's of note that during the cause of this

26 study, ozone hole which is designated by concentration less than or equal to 220DU was not recorded.

27 The highest and the lowest value of TCO is 295DU and 227DU respectively with an average range of 68DU.

Keywords: Total column ozone, Inter-tropical discontinuity, Mann-Kendall, West Africa. 


\section{Introduction}

32 The study of ozone has been on the increase by climate researchers all over, in the past few decades, this is due to the known effect and influence Ozone has on atmospheric processes which cannot be over emphasized. Ozone, with the empirical formula (O3), is a triatomic molecule composed of three oxygen atoms which is mostly found in the stratosphere, where it shelters humans from the Sun's unhealthy ultraviolet radiation (UV) (Akinyemi and Oladiran, 2007, Eresanya et al., 2017). its quantity in the atmosphere is very small when compared with other gases. (Kondratyev and Varotsos 1996, Efstathiou et al. 1998). O3 is an essential chemical element of the atmosphere that affects the energy budget and chemistry of the atmosphere along with air quality and global climate change (Duenas et al., 2004; Ahammed et al., 2006; Lin et al., 2008; Nishanth et al., 2014). This gas is mostly created by photochemical processes, although it may also be produced when a soothing electric discharge passes over oxygen. (Akinyemi, 2010). As a result, during electric storms, it can be produced in exceptionally small quantities. Because of its capacity to absorb both incoming solar UV and portion of visible light, as well as re-emit and absorb outgoing terrestrial infrared (IR) radiation, ozone has been acknowledged being one of the most prominent radiative gases in the stratosphere and upper troposphere. As a result, variations in ozone concentrations have an effect on climate, which is dependent on the altitudes at which the changes occur. (Bojkov and Fioeltov, 1995; Orsolini et al., 1998).

Transport mechanisms are the primary source of changes in the lower atmosphere. Ozone in the lower stratosphere serves as a tracer of atmospheric movements as a result of this activity. The dynamics of motion in the atmosphere are linked to this motion. The stratosphere's transport and wind motion are linked to that of the troposphere; For instance, at the tropopause, ascending air is carried into the stratosphere and expelled from the column at higher heights above a tropospheric high-pressure system. Because the ozone-mixing ratio in the lower stratosphere rises with altitude, the air entering this column has less ozone than the air leaving it. The quantity of ozone in the column drops as a result. As it advances, this high-pressure system drags the low-ozone column after it. This explains why high-pressure systems are connected to reduced stratospheric ozone levels. A low-pressure system has the opposite effect, causing a rise in ozone levels (Cordero and Forster, 2006). The tropical region produces the maximum stratospheric ozone, which slowly disperses towards the midlatitude and polar regions due to the effect of Brewer-Dobson circulation. In this circulation, Tropical air ascends from the troposphere to the stratosphere, moving towards higher latitudes, and then descends into the troposphere around mid-latitude while in the stratosphere over the polar area in this cycle. 
(Brewer, 1949 and Butchart 2014). The highest concentration of ozone over the mid-latitude and polar regions is due to this phenomenon, as opposed to the tropical area. The majority of ozone research is conducted in the mid-latitude and polar areas, where ozone depletion is more severe than it is in the tropics. (Farman et al., 1985). The variations in stratospheric ozone are sensitive to solar activity, atmospheric circulation and the angle of the sun's radiation.

The convergence of the trade winds of the two hemispheres is the fundamental description of InterTropical Discontinuity (ITD) (southern and Northern). Low pressure, rising motion, clouds, and precipitation characterize this system. In other words, the onset, retreat, and length of the rainy season in the tropical area are governed by two air masses meeting at a slanting surface with a sun synchronous movement.

During the months of March and April, ITD spreads from the Gulf of Guinea coast to the north. This signifies the beginning of the first rainy season along the Guinean coast south of $100^{\circ} \mathrm{N}$. (Sultan and Janicot,2003). The ITD continues to spread inland over the next few months (Lothon et al., 2008), reaching its northernmost climatological location in July and August at around 210N. (Sultan et al., 2007).

The ITD location does not change over several months, but it is influenced by a variety of processes at different time scales, ranging from daily low-level jets (Flamant et al., 2009) to multi-day pulsations with cycles of approximately 5 days (Couvreux et al., 2010). The ITD is positioned in the equatorial trough, a continuous low-pressure region that marks the geographic equator. Surface trade winds converge to generate a zone of heightened mean convection, cloudiness, and precipitation, transporting heat and moisture from surface evaporation and sensible heating.

\subsection{Data and methods}

\subsection{Description of the area of study}

This research focuses on the West Africa subcontinent, which is formed from the Africa continent. As indicated in Figure 1, the area spans latitudes $00 \mathrm{~S}$ to $25 \mathrm{ON}$ and longitudes $200 \mathrm{~W}$ to $200 \mathrm{E}$. Geographically, the Gulf of Guinea forms the southern border, while Mauritania, Mali, and Niger form the northern border. Its eastern and western boundaries are Mount Cameroun and the Atlantic Ocean, respectively. Nigeria, Benin, Ghana, Niger, Togo, Cape Verde, Senegal, Gambia, Guinea-Conakry, Ivory Coast, Guinea Bissau, Liberia, Mali, Mauritania, Sierra Leone, and Burkina Faso are among the 16 nations that make up the region, which spans over 5 million square kilometres. The climatology of the West 
Africa region is governed by the Inter-Tropical Discontinuity's latitudinal movement (which is a northsouth movement), and the three main climatic zones are: Guinea coast (4ON - 8ON), Savannah (8ON $110 \mathrm{~N}$ ), and Sahel (11 O N-16 ON) according to the classifications defined in (Omotosho and Abiodun, 2007; Akinsanola et al., 2015). The Guinea coast is the southernmost point of the Atlantic Ocean, and it has a sub-humid climate with annual rainfall ranging between 1250 and $5000 \mathrm{~mm}$. This is the realm of the deciduous or semi-deciduous forest that is moist and dry throughout the year.

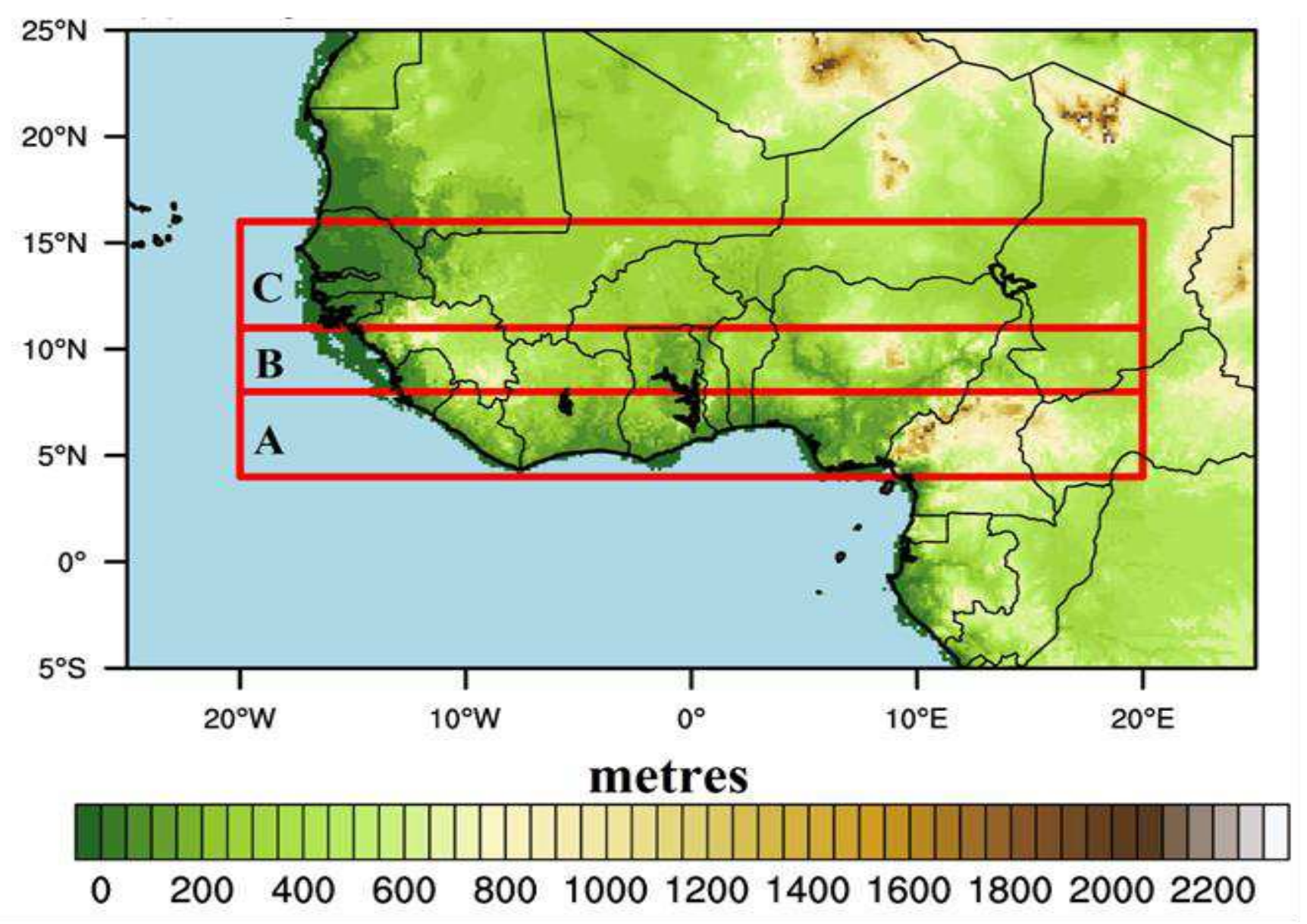

Fig. 1 Map of the study area, showing the western boundaries

The savannah zone is a semi-arid region with annual rainfall ranging from 750 to 1250 millimetres. The Sahel zone, which spans along the northern borders of Mauritania, Mali, and Niger, is characterized by a single rainfall peak (June to September) with an annual rainfall of approximately $750 \mathrm{~mm}$. The average annual temperature is usually over 18 degrees Celsius. The mean annual temperature in areas within 10 degrees north of the equator is roughly $26^{\circ} \mathrm{C}$, with a range of $1.7-2.8^{\circ} \mathrm{C}$ and a diurnal range of $5.6-8.3^{\circ} \mathrm{C}$. Even though the yearly range is $9^{\circ} \mathrm{C}$ and the diurnal range is $14^{\circ}$ to $17^{\circ} \mathrm{C}$, monthly mean temperatures 
between latitudes $10^{\circ} \mathrm{N}$ and the southern section of the Sahara can reach $30^{\circ} \mathrm{C}$. The average yearly temperature in the middle Sahara varies between $10^{\circ} \mathrm{C}$ and $35^{\circ} \mathrm{C}$ (Food and Agriculture Organization, 109 2001).

\subsection{Data Acquisition and Analysis}

111 Three datasets were utilized in this study: total column ozone, zonal wind, and dew point temperature.

112 The total column ozone dataset was derived from MERRA-2, the most recent global atmospheric 113 reanalysis for the satellite era generated by NASA's Global Modelling and Assimilation Office (GMAO) 114 using the Goddard Earth Observing System Model (GEOS) version 5.12.4. Zonal wind and dewpoint 115 Temperature was obtained from ERA-Interim which is produced by the European Centre for Medium

116 Range Weather Forecast (ECMWF). All data was obtained for the period between January 1980 to 117 December 2019 at $25 \mathrm{~km} \times 25 \mathrm{~km}$ resolution.

118 In order to delineate the position of Inter-Tropical Discontinuity (ITD) over the study region, the monthly mean convergence of the zonal winds for the study period was plotted and the line of vector discontinuity was derived. The delineated position was assessed with Monthly analysis of Spatio-Temporal variation of

121 total column ozone. This was carried out in order to determine the spatial distribution and temporal 122 variation along the inter-tropical discontinuity.

123 Long term variation of Total Column Ozone is represented by a linear regression equation given as;

$$
\mathrm{Y}=\mathrm{bx}+\mathrm{c}
$$

125 Where $\mathrm{x}$ is the monthly value of Total Column Ozone, And $\mathrm{Y}$ is the monthly mean of Total Column Ozone; where $b$ and $c$ are constants of regression. An equation which describes the temporal change of TCO 129 concentration. The equation for the trend is therefore given as:

131

$$
\text { ACRV }=\frac{\text { ANNUAL SD }}{\text { ANNUAL MEAN }} \times 100
$$

Where $\mathrm{SD}=$ standard deviation.

137 Where $\mathrm{x}$ is the observed TCO, and $\overline{\mathrm{x}}$ and $\mathrm{Sx}$ are the mean and standard deviation of TCO. 
Mann-Kendall test (Mk) (Mann 1945; Kendall 1975; Wang et al., 2005) was also used for the trend analysis. This was used to determine discontinuities due to inhomogeneous time succession. It is unique as it does not need presumptions analogous to data distribution. (Mondal et al., 2012). This makes it widely acceptable for trend analysis. (Ilori and Ajayi, 2020; Khan et al., 2020; Jonah et al., 2021) Mk statistic can be described as:

$$
K=\sum_{i=1}^{n} \sum_{j=1}^{i-1} \operatorname{sign}(x i-x j)
$$

Where $x i$ and $x j$ are the value of the sequential generic data, $n$ is the data total length, while sign(xi-xj) can be defined as;

The variance $\operatorname{Var}(\mathrm{S})$ was calculated as follows when $S$ statistic is approximately distributed with the $E(S)$ mean:

$$
\operatorname{Sign}\left(x_{i}-x_{j}\right)=\left[\begin{array}{ccc}
1, & \text { if }(x i-x j) & >0 \\
0, & \text { if }(x i-x j) & =0 \\
-1 & \text { if }(x i-x j) \cdots & <0
\end{array}\right]
$$

$$
E(S)=0,
$$

Where $\mathrm{t}$ is any given tie extent, $\sum \mathrm{t}$ represents the summation of all values of the tie number, while $\mathrm{n}$ denotes length of the series. The $Z$ standardized statistics for the test can then be evaluated using the equation below:

$$
\left\{\mathrm{n}(\mathrm{n}-1)(2 \mathrm{n}+5)-\sum_{\mathrm{t}} \mathrm{t}(\mathrm{t}-1)(2 \mathrm{t}+5)\right\}
$$

When a dataset of $\mathrm{n}$ variables is randomly distributed independently without trend and ordering is equally likely, the null $\left(H_{0}\right)$ hypothesis is accepted. The absolute value of $Z$ (test statistic) is then compared with the value of $Z\left(1-\frac{p}{2}\right)$ at $p$ level of significance obtained from the table to reject or accept the $H_{0}$ hypothesis.

$$
Z=\left(\begin{array}{ccc}
-1, & \text { if } & \mathrm{K}<0 \\
0, & \text { if } & \mathrm{K}=0 \\
\frac{\mathrm{S}+1}{\sqrt{\operatorname{Var}(\mathrm{S})}} & \text { if } & \mathrm{K}>0
\end{array}\right)
$$




\section{Data Description}

$\begin{array}{lllll}\text { DATA } & \text { SPATIAL } & \text { TEMPORAL RESOLUTION } & \text { SOURCES } & \text { UNITS } \\ & \text { RESOLUTION } & & & \\ \text { Total column Ozone } & 0.25 \times 0.25 & \text { Monthly } & \text { GIOVANNI } & \text { Du } \\ \text { Dew Point Temperature } & 0.25 \times 0.25 & \text { Monthly } & \text { ERA Interim } & \text { Kelvin } \\ \text { Uwind, Vwind } & 0.25 \times 0.25 & \text { Monthly } & \text { ERA Interim } & \mathrm{m} / \mathrm{s}\end{array}$

165 Table 1: Data source, type and description.

166 The zonal and meridional wind data were downloaded at standard height of $10 \mathrm{~m}$ above the ground level

\section{RESULTS AND DISCUSION}

169 The Inter-Tropical Discontinuity over land is a low-pressure system generated when the northeast and 170 southwest trade winds meet near the Earth's equator in West Africa. It's important to stress that the ITD 171 is a zone rather than a demarcation line; however, the Inter-Tropical Front (ITF), which is the same as the 172 ITD's northernmost boundary, is defined as a line. ITD which is generally used to represent the boundary 173 between the dry north winds and the warm humid winds to the south (Griffiths \& Soliman, 1972; Kalu, 174 1977; Dubief, 1979; Adeyefa et al., 1995).

175 The convergence points of the northeast and the southwest wind streamlines was considered to be the 176 average surface position of the ITD over the region on daily basis. 


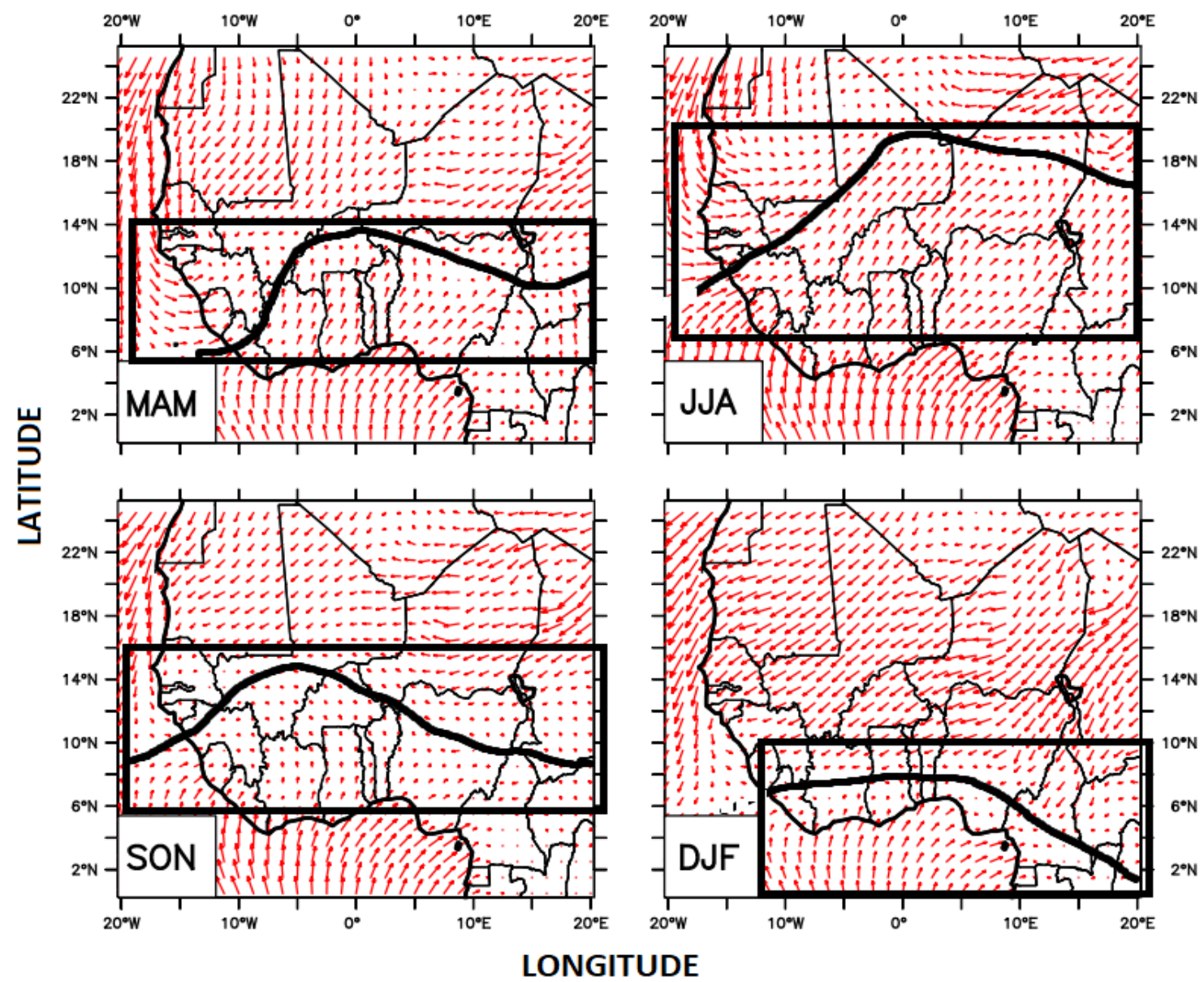

177

178 Fig. 2 Seasonal position of ITD over the study region 


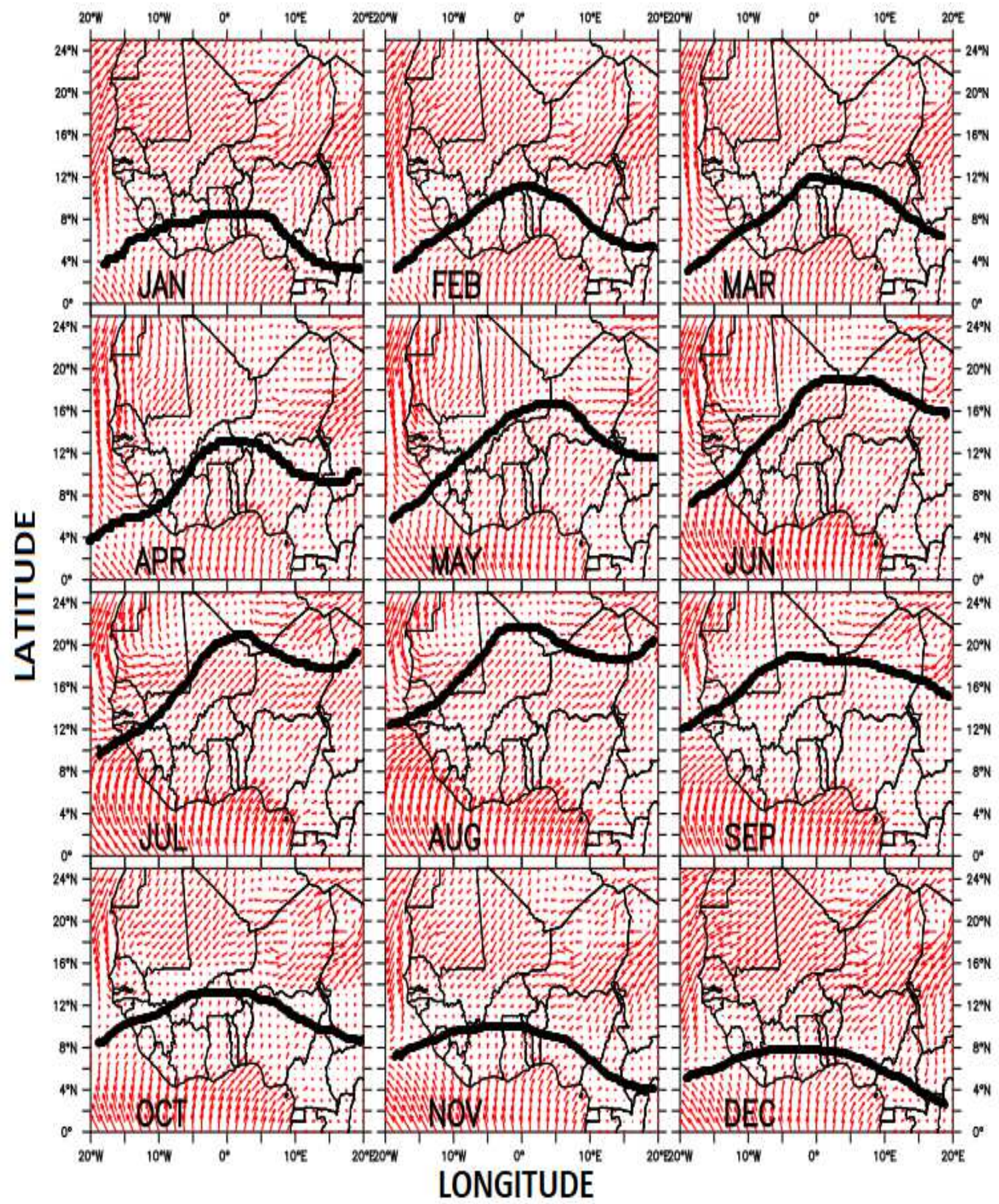

179

180

Fig. 3 Monthly mean position of ITD from January to December 
181 The figure 3 shows the monthly mean position of ITD for a period of 10 years (2010-2019). While figure 2 182 shows the seasonal position of ITD for a period between 1980 to 2019. ITD can be observed to be between $183 \quad 2-22^{\circ} \mathrm{N}$ for the monthly position and between $2-20^{\circ} \mathrm{N}$ for the seasonal position. The surface wind 184 convergence and dew-point temperature of $15^{\circ} \mathrm{C}$ was used to delineate this position. Using surface wind 185 convergence to delineate the position of ITD over West Africa is a widely accepted method as it takes into 186 consideration the surface level wind convergence which denotes the meeting point of two airmasses. 187 (Odekunle, 2010; Lele and Lamb, 2010; Oluleye and Jimoh., 2017) The northernmost position is seen to 188 be at the northern boundary of West Africa at $22^{\circ} \mathrm{N}$. The black continuous line shows the position of ITD 189 at each month over the region, as illustrated in figure 2 and 3.

190 Wind direction and dewpoint temperature for each month was averaged through a span of 10 years and 191 the monthly and seasonal mean value was derived over the study area. The most significant movement of 192 ITD was observed at June, July, August (JJA) with its northernmost position at $20^{\circ} \mathrm{N}$, while it extended from $19310^{\circ} \mathrm{N}$. While the season with the least variation was observed at MAM (March, April, May) which span 194 between $6-14^{\circ} \mathrm{N}$, similar observation was also made at SON (September, October, November). West Africa 195 has two major distinct seasons, namely wet and dry season. Wet season ranges from JJA and SON, while 196 dry season range from MAM and DJF. These dry months has the lowest propagation of ITD, while 197 significant observation was recorded during the wet months as in JJA and SON.

198 The positions of ITD in this study can be seen to be symmetrical with rainfall pattern over West Africa, as 199 ITD is the major indicator of rainfall system as observed by kalita et al., 2011. 


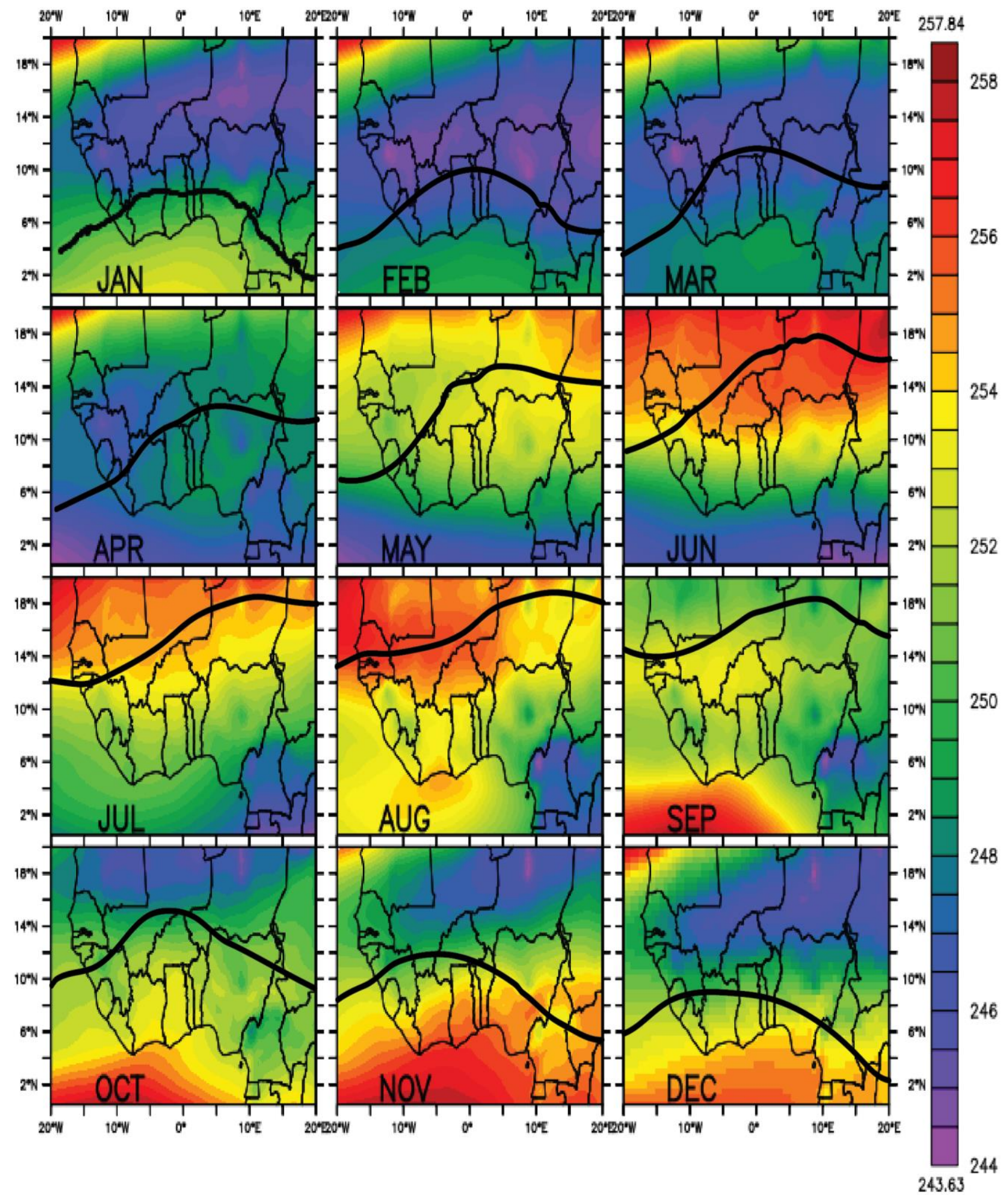

204 Fig. 4 Monthly distribution of Total column ozone over the West Africa Region, For a period between 2052000 to 2019. 


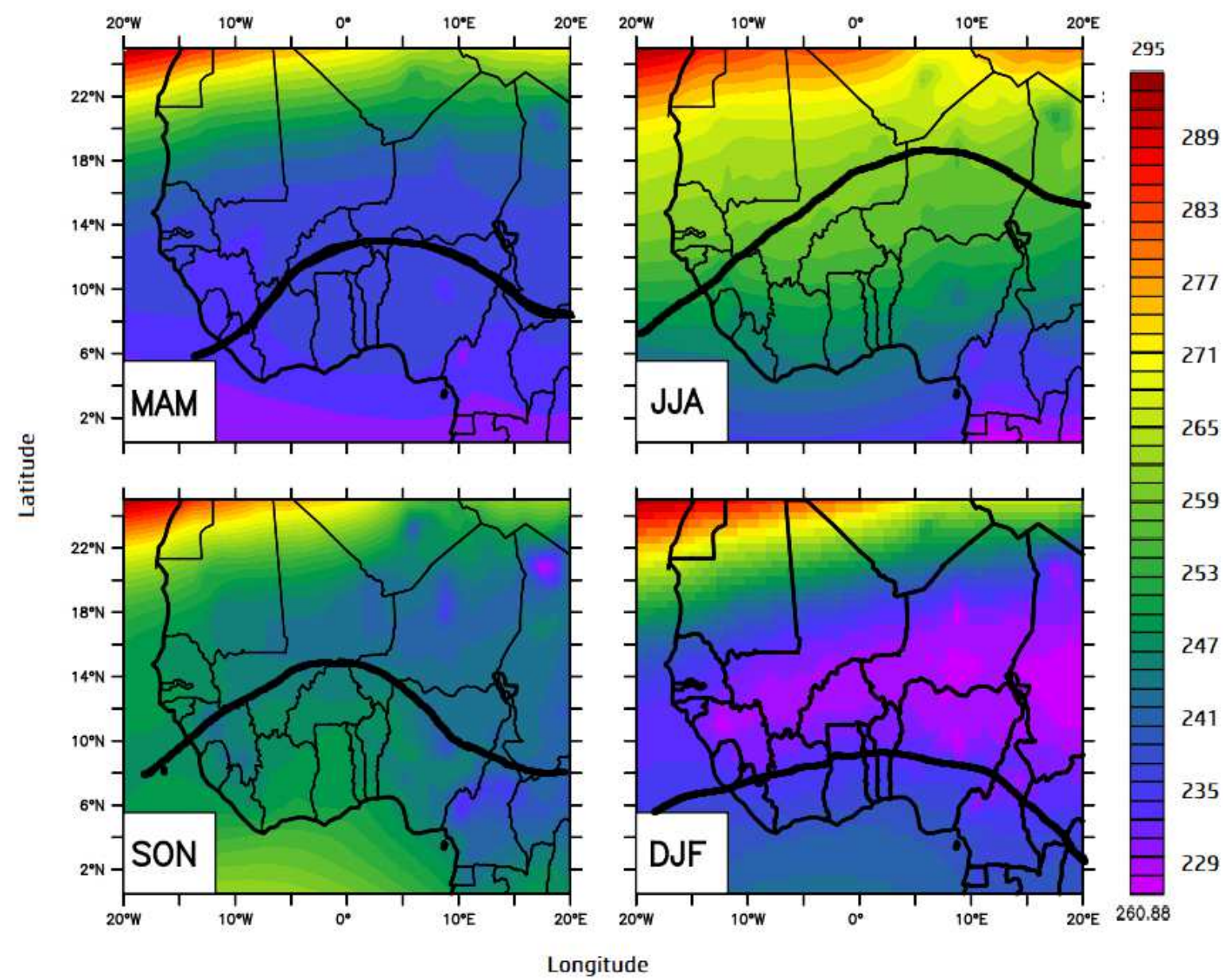

Fig. 5 Seasonal position of ITD with spatial distribution of Total column ozone over West Africa from a period between 1980 to 2019 .

209 Figure 5 depicts TCO range to be between 227-295 DU from January to December which shows a difference of $68 \mathrm{DU}$. The black line shows the position of ITD over the region for each month as previously delineated and observed in figure 2 and 3. From figure 4 ITD position over West Africa in the dry months

212 shows that regions south of the ITD which is dominated by the southwest trade wind exhibit a higher 213 concentration of TCO while region north of the ITD which is dominated by northeast trade wind has a 214 lower concentration between depicted between latitude $8-14^{0} \mathrm{~N}$, this phenomenon may be attributed to 215 the dominance of the Northeast trade wind over the region. The ITD trough itself is seen to have a considerable low concentration of TCO which is considered to be averagely low in the dry months. As also 217 observed in figure 5. In DJF, north easterly wind dominates most of West Africa region as indicated, also 218 the concentration of TCO over DJF is seen to be at its lowest. The ITD position slants, propagating along the West African coast lines from latitude $9^{0} \mathrm{~N}$ to $2^{0} \mathrm{~N}$ across the West to east region of West Africa, 
220 indicating a dry period of the year when an observation at the wind system for the month of April indicates

221 that southwesterlies have gained momentum over the northeasterlies this is observed as the ITD position

222 is seen to be located at $13^{\circ} \mathrm{N}$ and this also signals the beginning of rainfall for most West African region.

223 In February also, the concentration is also low along the ITD trough, but with a considerably higher value

224 than TCO concentration in January. In comparison, TCO has a higher concentration in January than

225 February. Also in March, the ITD position is seen to have moved northward by $2^{\circ} \mathrm{N}$, region of the ITD

226 trough is also observed to have a lower concentration of TCO than the surrounding region. April and May

227 also have the same low concentration along the ITD trough.

228 JJA have different condition, the concentration of TCO in this month is relatively higher than other months,

229 these months are also months when ITD is at its peak and the southwesterlies wind are dominant which

230 is also regarded as the rain peak over west Africa.

231 As the moist south westerly wind stabilizes over the region in JJA when ITD is reaching its northernmost 232 position as observed in figure 2 and 3, ozone concentration is seen to significantly increase in 233 concentration and propagation of ITD is observed to be at its peak. however, in September when ITD 234 begins to retreat, also marks the beginning of ozone decrement which wind up in returning to January 235 situation as the dry north easterly wind, once again, takes over the region in December. This illusive 236 transition of ITD corresponding changes in ozone concentration during the course of the year may be a 237 factor that makes weather activity most influencing factor, controlling TCO in West Africa as also observed 238 by Oluleye and Okogbue, 2013.

239 The totality of West Africa generally has a higher concentration of TCO in the month of JJA. It is also 240 observed that ITD region maintained it lower concentration while south of ITD has the highest 241 concentration of TCO. The trend also increased progressively from January and peaked at September, 242 which is also denoted as the ITD peak, and starts decreasing from October through February as previously 243 explained. In a recent study by Nishanth et al., 2021, similar observation was made over India which share 244 the same regional characteristics as west Africa as it is also a tropical region, he however attributed these 245 changes to some other meteorological variables. In a model study by (Haigh, 1994) revealed that a 1\% 246 increase in Ultra-violet (UV) radiation at the maximum of a solar cycle will generate a $2 \%$ increase in ozone 247 concentrations in the stratosphere. The results from this study agrees with a study by Nishanth et al., 248 2021, where he also observed significant increase in TCO concentration in months of June, July and August 249 which also has the highest concentration in this study, which he attributed to south-West monsoon over 250 the delineated locations. 


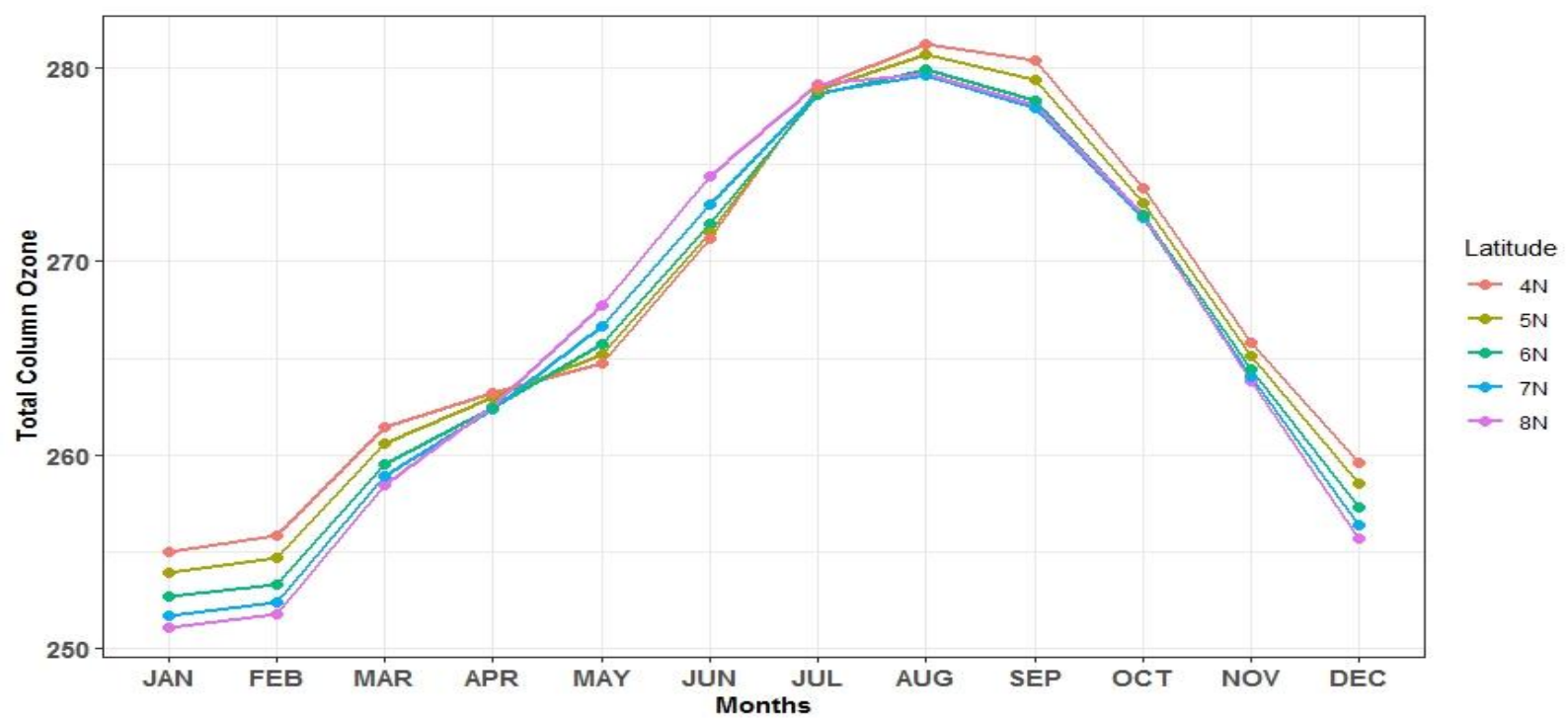

252

253

Fig. 6 Monthly variation of Total column ozone over the Guinea-Coast

TCO trend over the guinea coast established a relationship between ITD and Ozone as shown in figure 6. The guinea coast is a region of maximum precipitation, when compared to the Savannah and Sahel, it lies between $4-8^{0} \mathrm{~N}$. The maximum concentration of TCO occurred in August. while July, August, September is observed to have the highest concentration of TCO over the guinea coast. This feature is most likely linked to increase rainfall, cloud cover, large wind speed and lower atmospheric temperature which are the features of wet season in the guinea coast.

During the month of January, February, March and December, which has notably the lowest concentration of TCO, this may also be linked to atmospheric phenomenon associated with the dry period which include, more sunshine hours, high temperature, low humidity, sparse cloud cover. The highest concentration of TCO occurred in July over the guinea coast, while the minimum concentration occurred at January, February and December, which is associated with little or no rainfall over the West Africa region. Generally, High concentration were observed between June to September, with concentration between 270DU282DU, which can be attributed to increased monsoon rainfall. While low concentration was observed between January-March, which signals the Northward advancement of ITD and November-December, which also signals the retreat of ITD over West Africa.

Also, across the latitude, lower latitude is observed to have a higher concentration of TCO, while higher latitude is observed to have a lesser concentration as seen in figure 6 , the study of the trend between latitude $4^{0} \mathrm{~N}$ and $8^{0} \mathrm{~N}$ revealed the variability between the latitudes. As they all increase steadily between 
271 January and march, interchanging positions at April, as it is observed that concentration at $8^{0} \mathrm{~N}$ is now 272 higher that TCO concentration at $4^{0} \mathrm{~N}$. From May through July, this progression is continued before 273 reverting to the initial position. The presence of ITD, which influences the concentration of ozone across 274 this latitude, is responsible for this divergence.

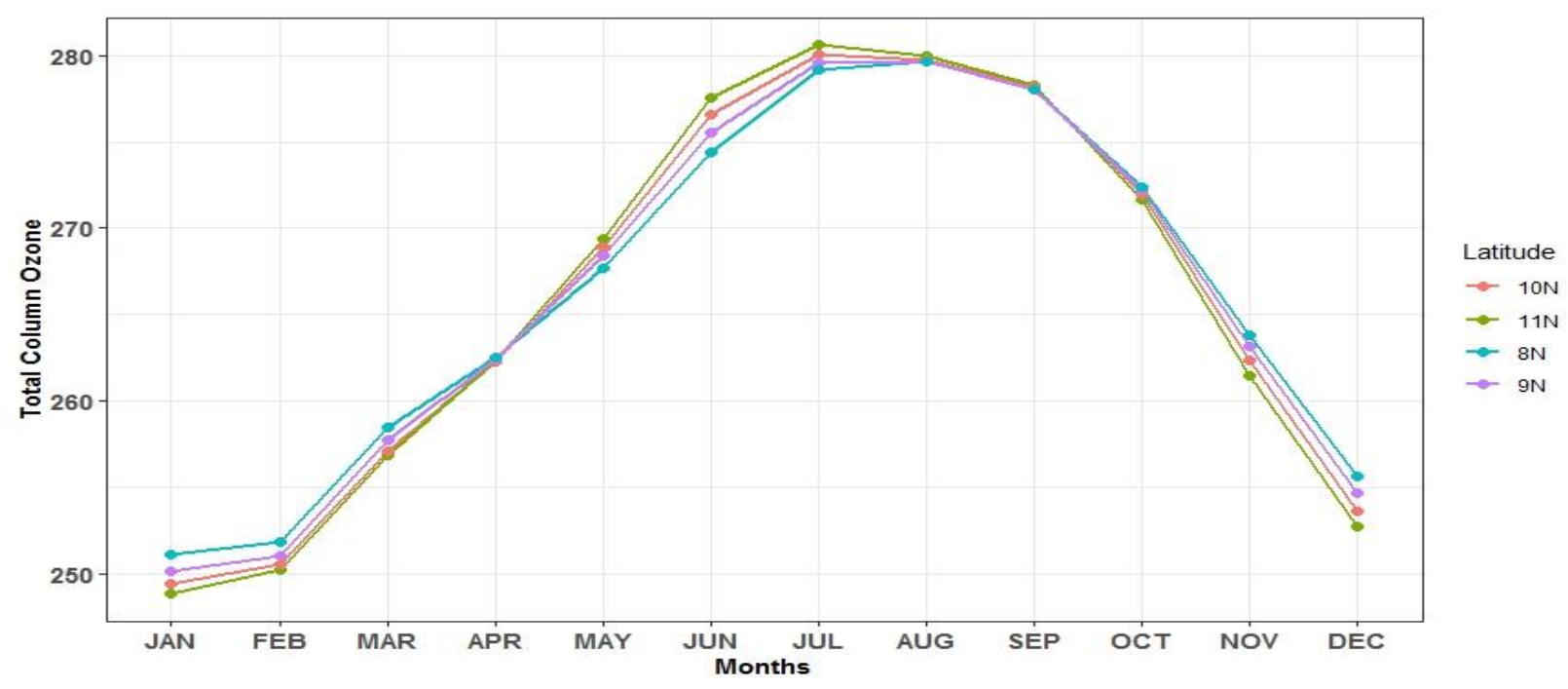

Fig. 7 Monthly variation of Total column Ozone over the Savannah

277 Figure 7 further describe TCO variation across latitude as observed over the savannah region. Savanah 278 region is situated between latitude $8-11^{\circ} \mathrm{N}$, it has lesser precipitation when compared to the guinea coast. 279 Maximum concentration is also at July with a TCO concentration of $280 \mathrm{DU}$ at $11^{0} \mathrm{~N}$ as compared to Guinea 280 coast which peaked at august and a TCO peak of 282DU. Over the savannah region, June, July, august and 281 September has the highest concentration with a difference of less than 5DU as compared to the Guinea coast which has a difference of about 10DU, while DJF still maintained the lowest concentration over the region.

284 This region exhibits a significant difference from the Guinea coast has observed in January, latitude $8^{0} \mathrm{~N}$ 285 has the highest concentration of TCO till April, which signals the movement of ITD to this latitudinal position. The concentration drops to being the lowest at April. The concentration is reversed from 11$2878^{0} \mathrm{~N}$ throughout till TCO peak at July as opposed August of the previous zone. Then at august, the 288 latitudinal position concentration is maintained till October which is also revert back the TCO 289 concentration at each latitude to the initial position. These changes can also be attributed to the presence of ITD at this region in the month such as January, April, August and October. 
291 The savannah region is observed to be less concentrated than the guinea coast. As it has much lower 292 concentration in December, January, February progressively till it peaked at July when compared to 293 Guinea coast.

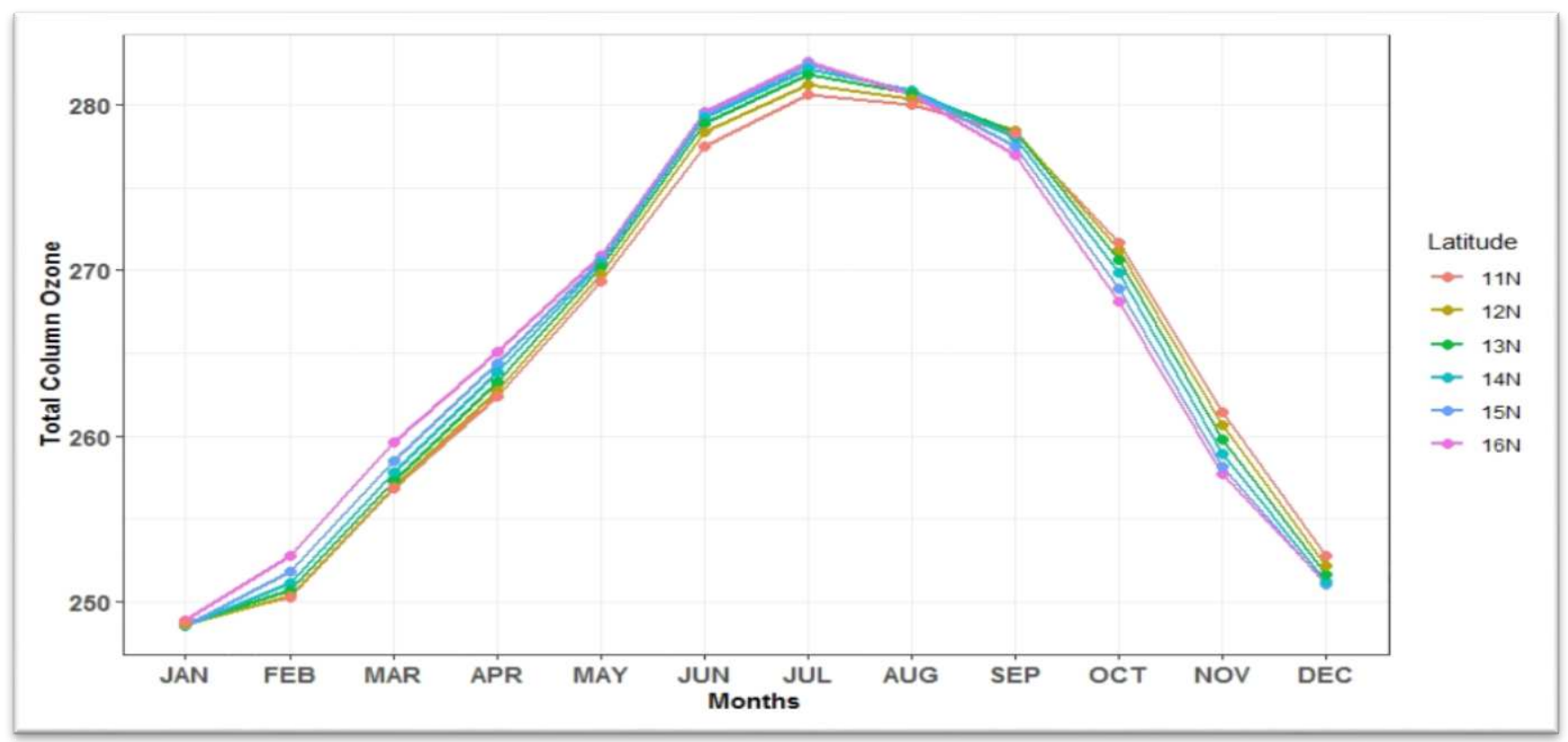

294 Fig. 8 Monthly variation of Total column Ozone over the Sahel

295 While over the Sahel, which is regarded as the driest region which has the least impact of ITD. TCO is 296 observed to have the same value for January across the six Sahelian latitudinal region. It is also observed 297 to peak at July as same with the savannah region. However, latitudinal positions are maintained till august, 298 which over Sahel region signifies the beginning of the dry season. This also correlated with the position of 299 ITD as observed in figure 4, over the months and across latitudinal regions shows that June, July, August and September are months were ITD position is northernmost. 


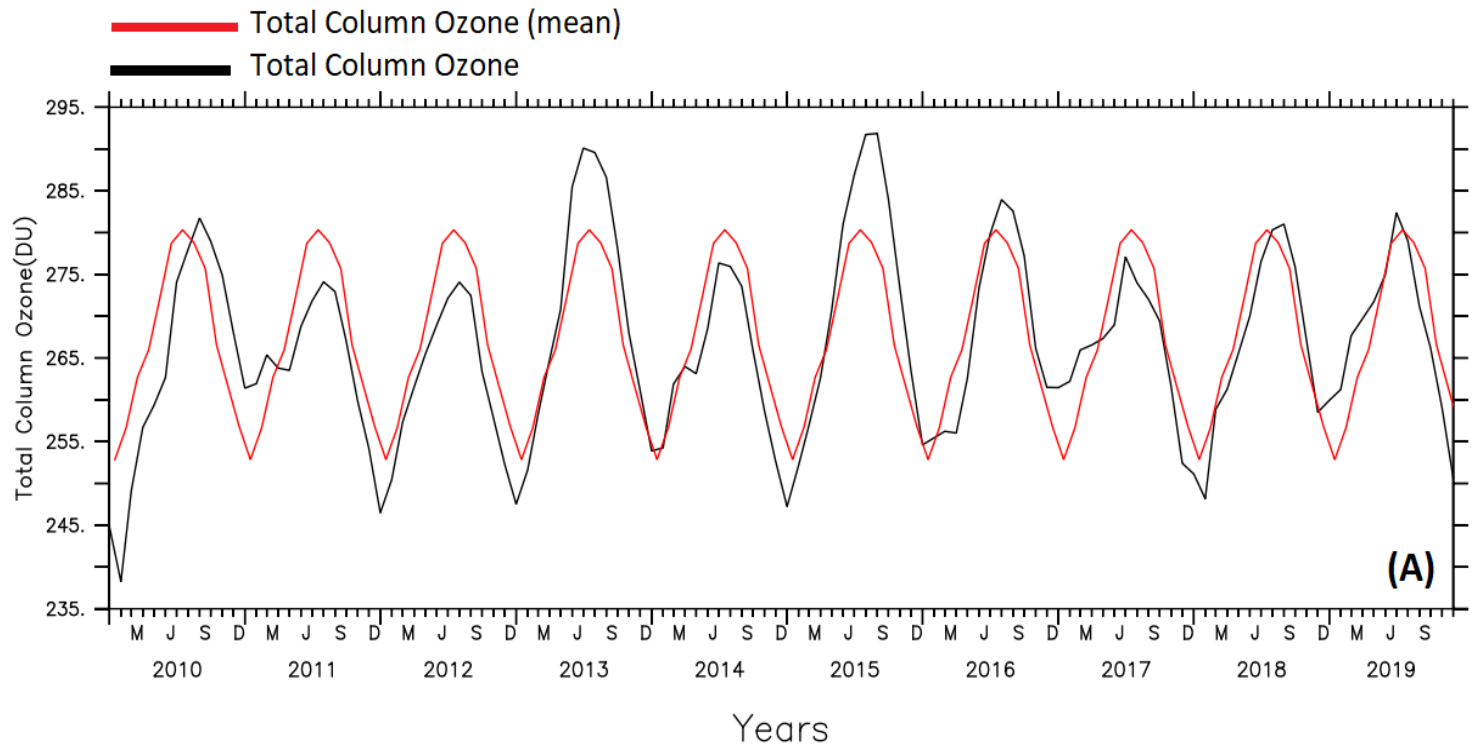

301

Fig. 9 Annual Trend of TCO Over the Guinea Region

Figure 9 shows the annual and mean trend of TCO over the guinea coast. The guinea coast region which

304 has the presence of ITD almost throughout the year is observed to have a significant minimum value in

305 the month of February in 2010 and maximum at August in 2015. While the mean range is between 253 and 280 DU over the Guinea coast. The minimum and maximum value for TCO in this region is 238 and

307292 respectively. The trend also indicates a pattern along which ITD propagates. From

308 January/December to July/august, there seems to be a significant progressive increment in the value of

309 TCO across the study period and a decrease in the concentration from July/August to

310 December/January. These establishes a relationship between ITD movements across the months and

311 Total column ozone concentration along the region. the lowest concentration of TCO was observed at

312 February 2010 while the highest concentration was observed at July/August 2015. 


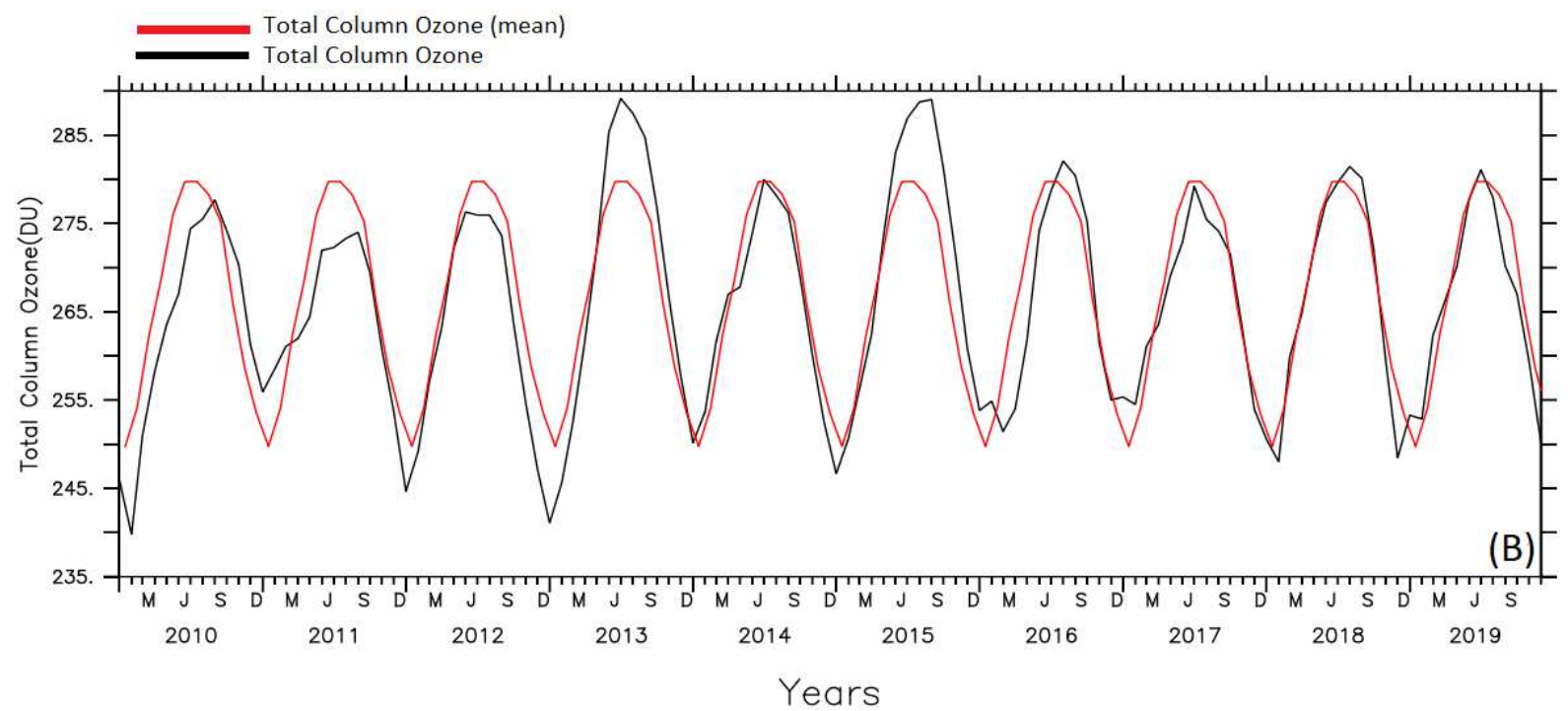

313

314

315

316

317

318

319

320

321

322

323

Fig. 10 Annual Trend of TCO over the savannah region

Figure 10 shows annual and mean trend of TCO over the savannah region. Which is located between latitude $8-11^{0} \mathrm{~N}$. the trend is similar to the trend over the Guinea coast but of lower TCO concentration, with a minimum of $240 \mathrm{DU}$ and a maximum concentration of $289 \mathrm{DU}$, with a difference of 49DU, from the minimum concentration in January/December to the maximum concentration in July/august and also a mean minimum value of $250 \mathrm{DU}$ and mean maximum concentration of $280 \mathrm{DU}$, with a mean difference of 30DU. the lowest concentration of TCO was observed at February 2010 while the highest concentration was observed at June 2013.

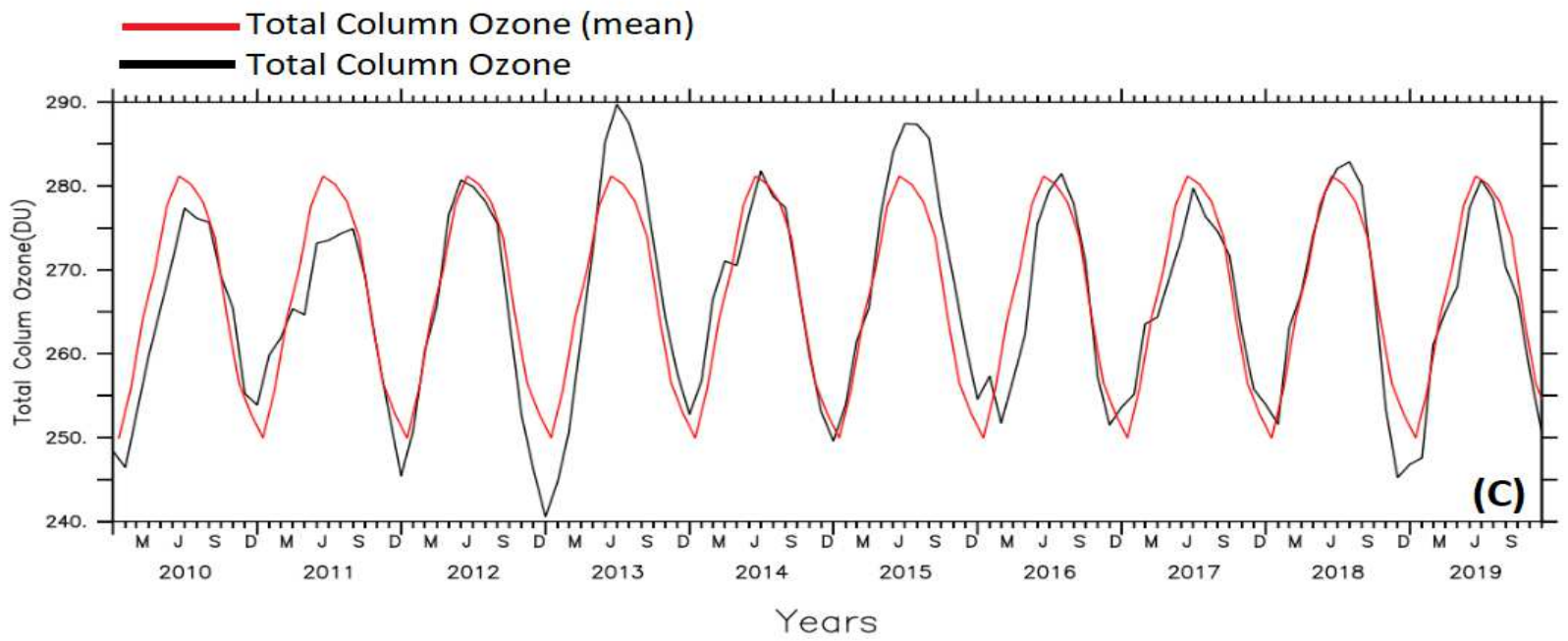

Fig. 11 Annual Trend of TCO over the Sahel region 
Figure 11 shows annual and mean trend of TCO over the Sahelian region, which is located between latitude

$32512-16^{0} \mathrm{~N}$. the trend is similar to the trend over both the Guinea coast and the savanna region, having also the same lower TCO concentration with the savannah region, with a minimum of 240DU and a maximum concentration of 290DU, with a difference of $50 \mathrm{DU}$, also with a minimum concentration in January/December to the maximum concentration in July/August and also a mean value of 250DU and maximum concentration of $282 \mathrm{DU}$, with a mean difference of 30DU. The major difference observed between savanna and Sahel region is the shift in months of lower concentration of ozone. It occurs over the savanna region majorly in November/December, while over the Sahelian region, lowest occurrence was observed in December/January. The lowest concentration of TCO was observed at December 2012 while the highest concentration was observed at June 2013.

334 In the year 2013 and 2015, in the month of June/July respectively, there is observed to be a significant increase in concentration of TCO, which may be attributed to factors other than the influence of ITD, similar observation was also made in the Guinea coast and savannah region.

337 Figure $12-14$ shows the regression trend at each latitude from $20^{\circ} \mathrm{N}-4^{0} \mathrm{~N}$. From $20^{\circ} \mathrm{N}-4^{0} \mathrm{~N}$, an increase in the variation of TCO is observed as the slope of the trend is positive. With the exception of $18^{\circ} \mathrm{N}$ and $19^{0} \mathrm{~N}$ which shows a negative trend/year. Throughout higher latitude, TCO seems to have it maximum concentration to be at 2013 from $20^{\circ} \mathrm{N}-12^{\circ} \mathrm{N}$ while from $11^{\circ} \mathrm{N}$ the maximum concentration also extends to 2014 making it a dual peak this is reflected as the coefficient of the slope at this region increases.

342 Similar observation was made by Nishanth et al., 2021 which he attributed to latitudinal variation he 343 also noted that changes in wind pattern influence changes in spatial and Temporal distribution of TCO.

344 Large inter annual variability of TCO concentration was also observed which is can be attributed to 345 variation in tropopause height, air circulation changes, changes in anthropogenic concentration and 346 other atmospheric factors. 

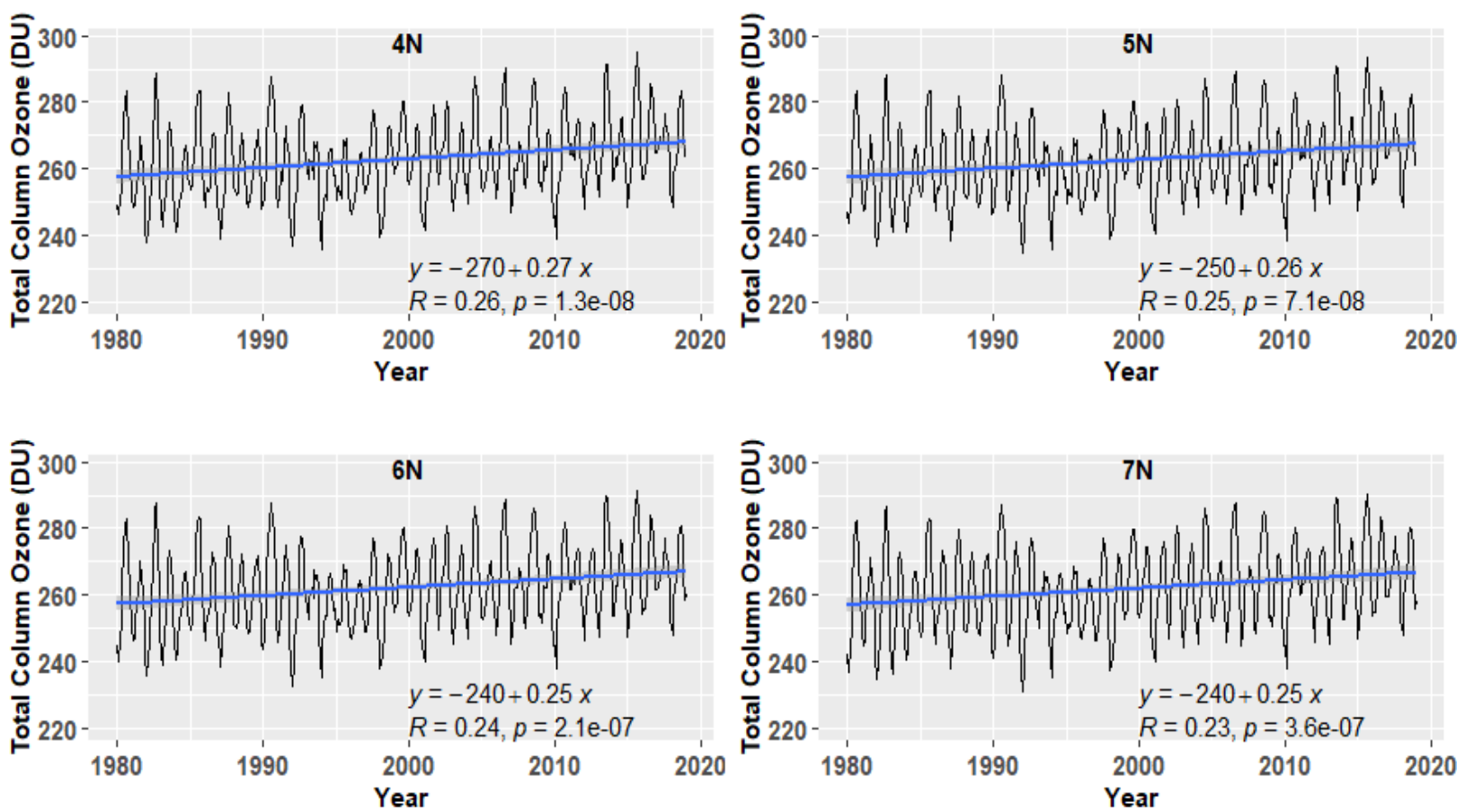

Fig. 12 Variation from $4-7^{0} \mathrm{~N}$ 

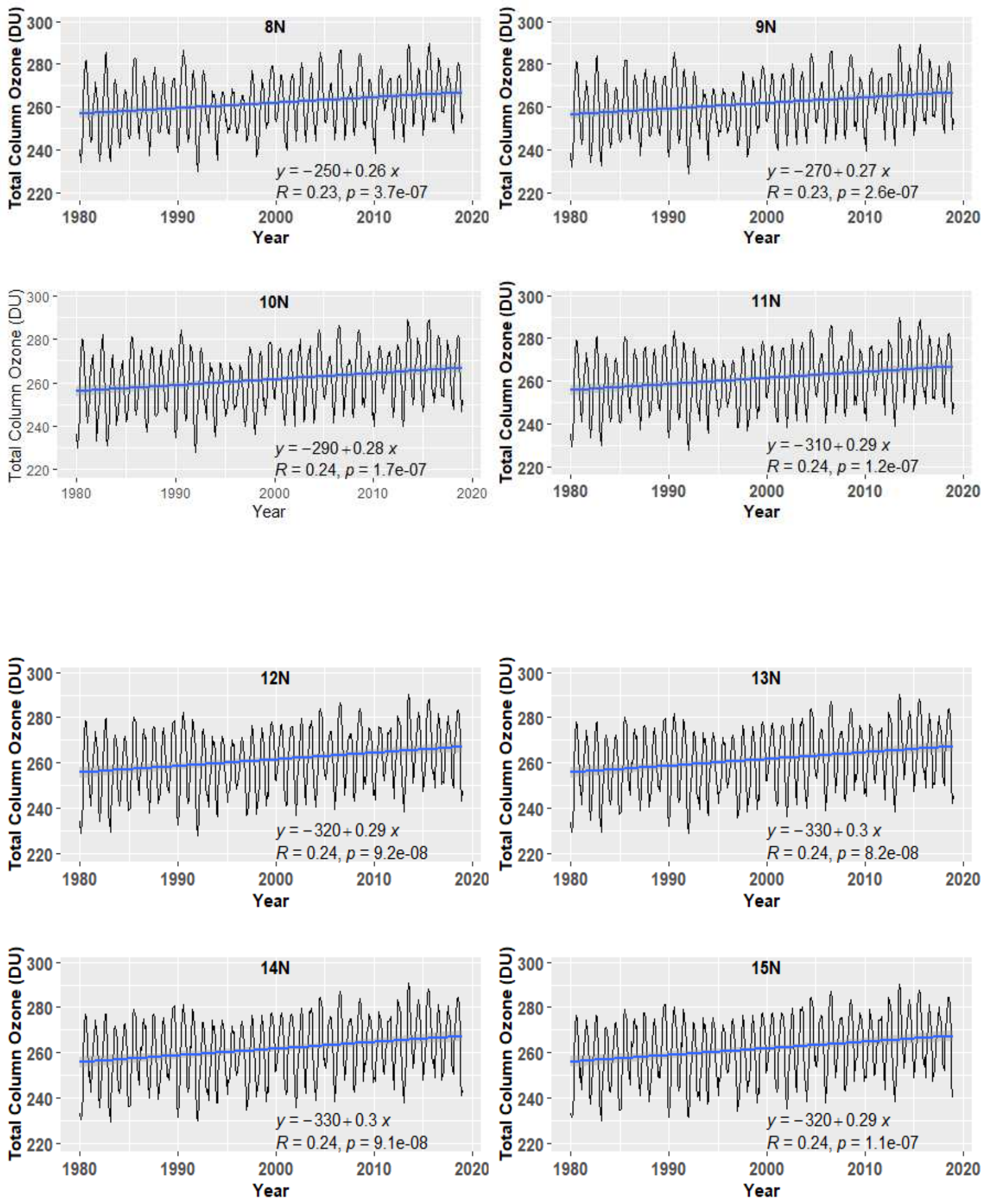

Fig. 13 Variation from $8-15^{\circ} \mathrm{N}$ 

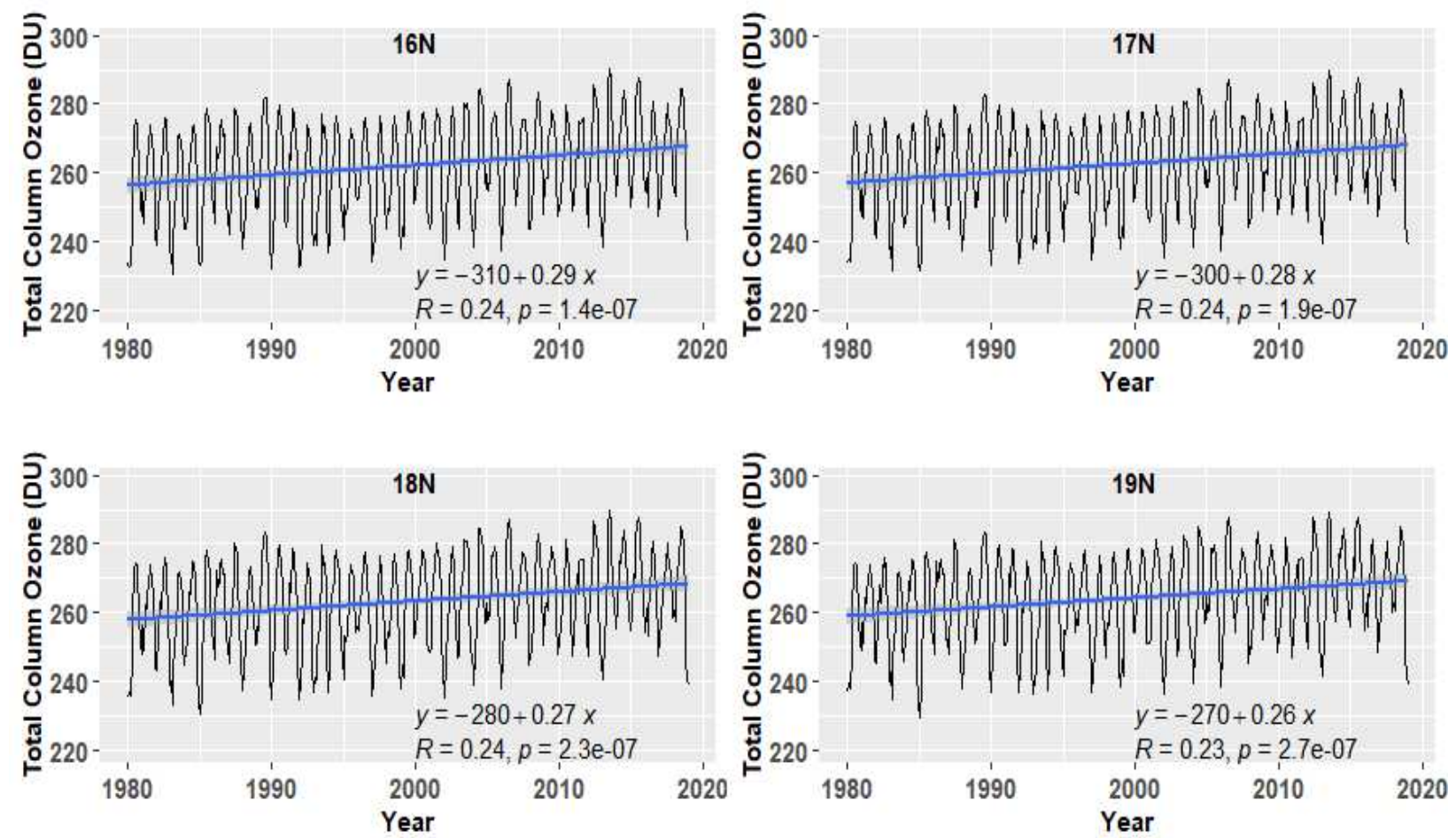

Fig. 14 Variation from $16-19^{\circ} \mathrm{N}$

363

364

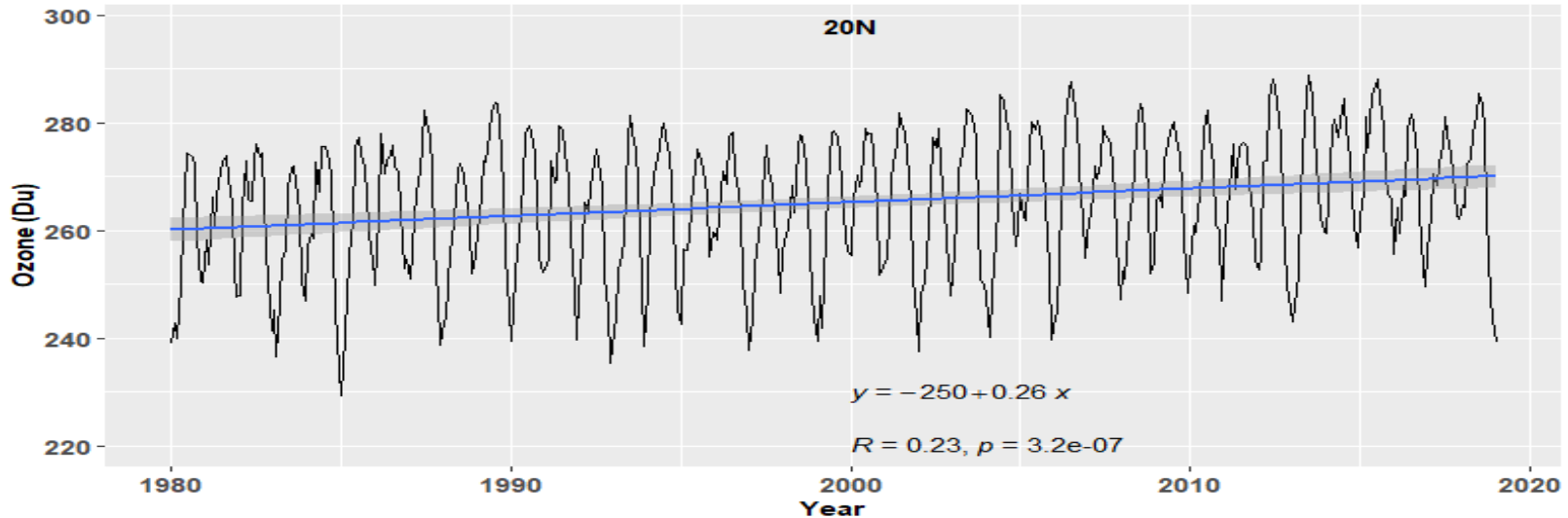

Fig. 15 Variation at $20^{\circ} \mathrm{N}$ 
371 Table 2: Statistical Summary

\begin{tabular}{|c|c|c|c|c|c|c|c|}
\hline Latitude & Mean & Minimum & Maximum & $\begin{array}{l}\text { Standard } \\
\text { Deviation }\end{array}$ & TREND/YR & ACRV & $\begin{array}{l}\text { Regression } \\
\text { Coefficient }\end{array}$ \\
\hline $20^{\circ} \mathrm{N}$ & 265.20 & 229.30 & 289.00 & 12.39 & 0.20 & 4.28 & 0.227 \\
\hline $19^{\circ} \mathrm{N}$ & 264.11 & 229.50 & 289.30 & 12.70 & -0.98 & 4.41 & 0.228 \\
\hline $18^{\circ} \mathrm{N}$ & 263.13 & 230.30 & 289.60 & 13.03 & -0.99 & 4.55 & 0.227 \\
\hline $17^{\circ} \mathrm{N}$ & 262.51 & 231.60 & 290.00 & 13.30 & 0.41 & 4.67 & 0.227 \\
\hline $16^{\circ} \mathrm{N}$ & 261.98 & 230.60 & 290.20 & 13.50 & 3.07 & 4.77 & 0.231 \\
\hline $15^{\circ} \mathrm{N}$ & 261.69 & 229.90 & 290.40 & 13.62 & 0.63 & 4.83 & 0.233 \\
\hline $14^{0} \mathrm{~N}$ & 261.58 & 229.40 & 290.60 & 13.65 & 0.99 & 4.84 & 0.239 \\
\hline $13^{0} \mathrm{~N}$ & 261.54 & 228.70 & 290.50 & 13.61 & 1.26 & 4.79 & 0.238 \\
\hline $12^{0} \mathrm{~N}$ & 261.42 & 227.90 & 290.10 & 13.49 & 1.48 & 4.75 & 0.237 \\
\hline $11^{0} \mathrm{~N}$ & 261.35 & 227.60 & 289.70 & 13.30 & 1.63 & 4.63 & 0.235 \\
\hline $10^{\circ} \mathrm{N}$ & 261.74 & 228.00 & 289.20 & 13.03 & 1.81 & 4.51 & 0.240 \\
\hline $9^{0} N$ & 261.92 & 228.90 & 289.20 & 12.72 & 1.94 & 4.37 & 0.232 \\
\hline $8^{0} \mathrm{~N}$ & 261.96 & 229.90 & 289.70 & 12.40 & 11.71 & 4.24 & 0.231 \\
\hline $7^{0} \mathrm{~N}$ & 262.22 & 230.90 & 290.40 & 12.11 & 2.21 & 4.17 & 0.232 \\
\hline $6^{0} N$ & 262.58 & 232.50 & 291.60 & 11.88 & 2.39 & 4.14 & 0.238 \\
\hline $5^{0} N$ & 262.89 & 234.50 & 293.30 & 11.74 & 2.47 & 4.15 & 0.248 \\
\hline $4^{0} \mathrm{~N}$ & 262.92 & 235.90 & 295.00 & 11.65 & 2.60 & 4.18 & 0.261 \\
\hline
\end{tabular}

372 .

373 

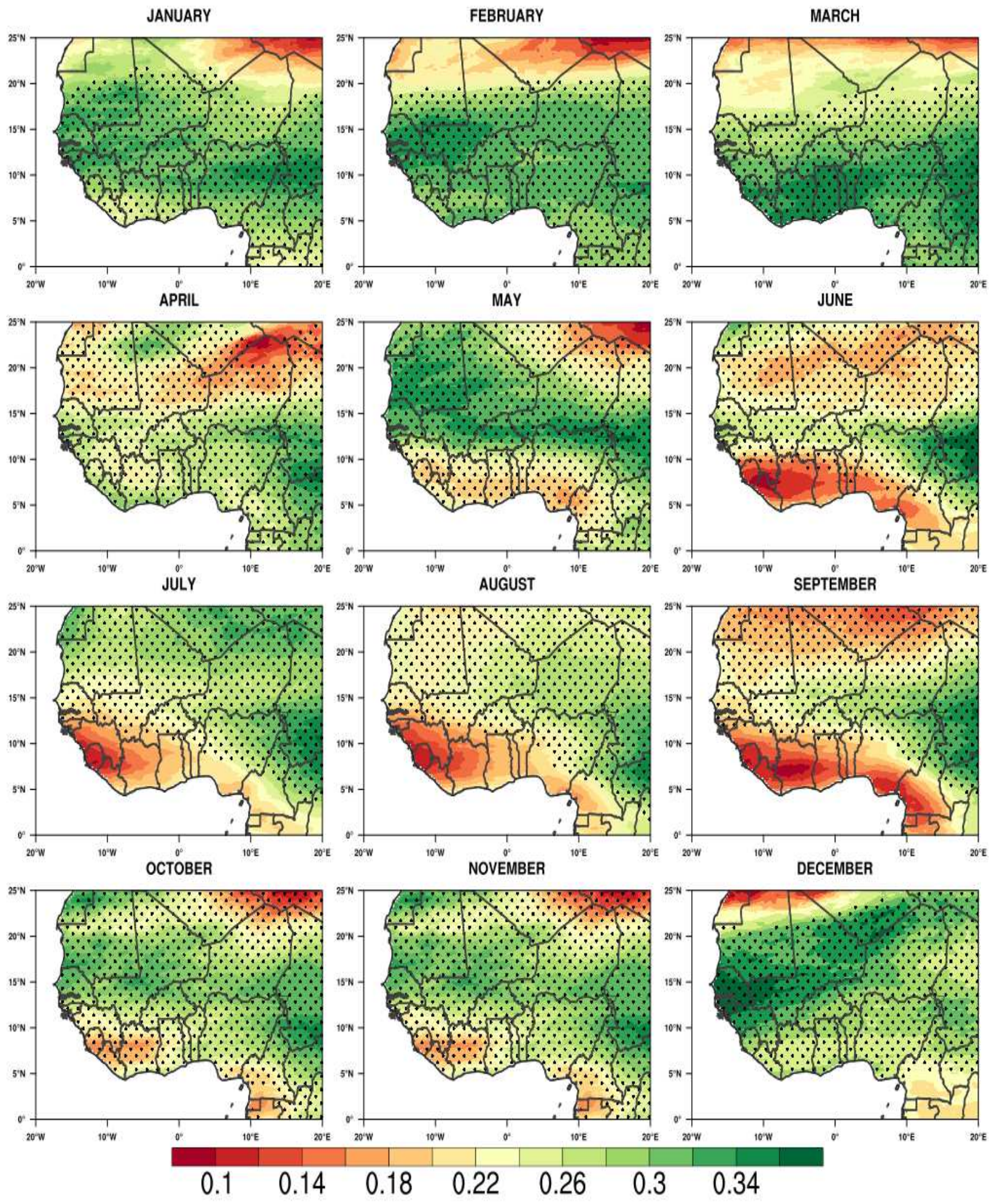

375 Fig. 16 Trend of Total column ozone over West Africa from 1980-2019; Region with black dots depict

376 where the trend is significant at $95 \%$ confidence level. 
The result of the Mann-Kendall (MK) trend analysis described by Mann (1945) and Kendall (1975) was

378 performed at 95\% confidence level for the months over the study region. The result shows that, there is

379 an increasing trend over the months in the study area. With magnitude of change to be between 0.1 to

$380 \quad 0.34$. High magnitude was observed during the dry months and considerably low during the wet months.

381 High level of significance was observed in all the months, with the highest in November, which marks

382 the end of the wet season and the lowest in march. as observed in figure. 16 over the West Africa region. In December, January, February and March, between latitude 20 to $25^{\circ} \mathrm{N}$, the level of significant

384 is negligible and the trend over the area is also significantly low. While between latitude $4-20^{\circ} \mathrm{N}$, the trend is most positive over the region in these months. ITD position between these months is between $4-12^{\circ} \mathrm{N}$. over these months the low significance level observed maybe attributed to the outlying position of ITD. The tarrying months is in synchronization with the position of ITD over the region.

\section{CONCLUSION}

This study has examined and helped in understanding the influence of ITD on total column ozone over the period between 1980-2019, over West Africa using satellite data. Both geospatial and correlation analyses were performed to show variations in total column ozone and the influences of ITD over TCO in the period of study. In this study, ITD is delineated to propagate between $4-20^{\circ} \mathrm{N}$ of the equator. The literature review has provided an insight to the characterization, propagation and significant of ITD over West Africa based on scientific literatures.

395 This study, on the other hand, has provided an update on the trend and connection between these two distinct variables across the West African subcontinent. According to Oluleye and Okogbue (2013), there are additional variables that regulate ozone concentration, with bush burning being the most important. Bush burning is primarily responsible for the generation of photochemically reactive gases such as NO, CO, and hydrocarbons, which combine to create ozone. The assumption is that the dry season is best for ozone generation since there is apparently a lot of biomasses burning going on during this period.

401 This is not the situation over West Africa, which has the lowest ozone concentration during the dry season.

402 The footprints of the burnings were found to have a minor impact on the overall temporal and spatial 403 distribution of total column ozone. Oluleye and Okogbue (2013) attributed this to the fact that lower 404 atmospheric ozone is primarily controlled by bush burning, while ozone in the upper atmosphere is 405 independent of fluctuating lower atmospheric ozone concentrations, according to Combrink et al. (1995). 406 As a result, the total ozone distribution aligns in the direction of the upper atmospheric ozone control 407 mechanism, which happens to be the ITD over West Africa. The influence of ITD over west Africa is more 
renowned during the dry months most especially in DJF that the wet months. However, lower

409 concentration is also observed in the dry months as opposed the wet months of JJA over the study region.

410 The major finding of this study is that TCO distributions vary over time and space, but there appears to be

411 a significance variation in the concentration of TCO along the ITD zone. Furthermore, the relationship

412 between ITD and TCO varies across latitudes but appears to be more significant between latitude $10-14^{\circ} \mathrm{N}$,

413 which is the savannah region. it's also noted that throughout this study, ozone hole which is designated

414 by concentration less than or equal to 220DU was not recorded. The highest and lowest concentration was

$415295 \mathrm{DU}$ and 227.60DU respectively which gives a difference of about 67DU.

417 Ethical Approval

418 Not Applicable

419 Consent for publication

420 Not applicable

421 Consent to Participate

422 Not Applicable

423 Competing Interest

424 Authors have declared that there is no competing interest in this research.

425 Authors Contribution

426 Ayomide Arowolo and Ayodeji Oluleye both participated to the interpretation, data analysis and the review

427 of the manuscript.

428 Funding

429 The author(s) received no financial support for the research, authorship, and/or publication of this article.

430 Acknowledgement

431 The authors are grateful to Copernicus Climate Change Service (C3S) Climate Date Store for making the 432 datasets available on their website, which may be accessed via the European Centre for Medium-Range 433 Weather Forecasts (ECMWF). And to the Giovanni online data system, developed and maintained by the 434 NASA GES DISC. Many thanks also go to the reviewers who will be evaluating this manuscript; your 435 feedback will be immensely cherished.

436 Data availability

437 The datasets analysed during the current study are available at Giovanni at https: //giovanni 438 .gsfc.nasa.gov/ giovanni/ and Era5 https://cds.climate.copernicus.eu/cdsapp\#!/dataset/reanalysis-era5439 single-levels-monthly-means?tab=form 


\section{References}

Adedokun, J.A., 1979. Towards achieving an in-season forecast of the West African precipitation. Archivfür Meteorologie, Geo physik und Bioklimatologie Serie A 28, 19-38.

Aculinin, A. (2006) Variability of Total Column Ozone Content Measured at Chisinau Site, Republic of Moldova. Moldavian Journal of Physical Science, 5, 240-248.

Adeyewa ZD, Oluleye A. Relationships between aerosol index, ozone, solar Zenith angle and surface reflectivity: A case study of satellite observation over Lagos; 2011.

Akinyemi L. The influence of some atmospheric phenomena on total ozone over the tropics. Australian Journal of Basic and Applied Science. 2007;1(4):497505.

Akinyemi, M.L. (2010). Total ozone as a stratospheric indicator of climate variability over West Africa. International Journal of the Physical Sciences. 5(5), pp. 447-451

Allen J. (2004). Ozone and Climate Change. National Aeronautics and Space Administration (NASA), Earth Observatory Release

Ayansina A., Godwin MA. Jegede O. Spatial and seasonal variations in atmospheric aerosols over Nigeria: Assessment of influence of intertropical discontinuity movement The International Journal of Ocean and Climate Systems. 2019; 1759313118820306

Bell, M. A., and P. J. Lamb, 2006: Integration of weather system variability to multidecadal regional climate change: The West African Sudan-Sahel zone, 1951-98. J. Climate, 19, 5343-5365.

Bhattacharya, R. and Bhoumick, A. (2012) Trend Analysis of Total Column Ozone over India Using TOMS Data from 1979 to 2010. International Journal of Engineering Science and Technology, 4, 21592166.

Bou Karam, D., C. Flamant, P. Knippertz, O. Reitebuch, M. Chong, J. Pelon, and A. Dabas, 2008, Dust emissions over the Sahel associated with the West African Monsoon inter-tropical discontinuity region: a representative case study, Q. J. R. Meteorol. Soc. 134: 621-634.

Bou Karam D., C. Flamant, P. Tulet, M. C. Todd, J. Pelon and E. Williams, 2009a, Dry cyclogenesis and dust mobilization in the Inter Tropical Discontinuity of the West African Monsoon: a case study, Journal of Geophysical Research.

Bou Karam D., C. Flamant, P. Tulet, J-P. Chaboureau, A. Dabas, and M. C. Todd, 2009b, Estimate of Sahelian dust emissions in the Intertropical discontinuity region of the West African Monsoon, Journal of Geophysical Research.

Chen, D. L., Nunez, M., 1998. Temporal and spatial variability of total ozone in Southwest Sweden revealed by two ground-based instruments. InternationalJournalofClimatology18,1237-1246. 
Combrink, J., Diab, R.D., Sokolic, F., Brunke, E.G., 1995. Relationship between surface, free tropospheric and total column ozone in two contrasting areas in South Africa. Atmospheric Environment 29, 685-691.

Corlett, G.K., Monks, P.S., 2001. A comparison of total column ozone values derived from the Global Ozone Monitoring Experiment (GOME), the Tiros Operational Vertical Sounder (TOVS), and the Total Ozone Mapping Spectrometer (TOMS). Journal of the Atmospheric Sciences 58,11031116.

C Dueñas, M.C Fernández, S Cañete, J Carretero, E Liger, Analyses of ozone in urban and rural sites in Málaga (Spain), Chemosphere, Volume 56, Issue 6, 2004, Pages 631-639, ISSN 0045-6535, https://doi.org/10.1016/i.chemosphere.2004.04.013. https://www.sciencedirect.com/science/article/pii/S0045653504002814)

Citeau, J., L. Finaud, J. P. Cammas, and H. Demarcq, 1989: Questions relative to ITCZ migrations over the tropical Atlantic Ocean, sea surface temperature and Senegal River runoff. Meteor. Atmos. Phys., 41, 181-190.

Diab, R.D., Thompson, A.M., Mari, K., Ramsay, L., Coetzee, G.J.R., 2004. Tropospheric ozone climatology over Irene, South Africa, from 1990 to 1994 and 1998 to 2002. Journal of Geophysical Research-Atmospheres 109, art.no. D20301.

Drobinski, P., S. Bastin, S. Janicot, O. Bock, A. Dabas, P. Delville, O. Reitebuch, and B. Sultan, 2009: On the late northward propagation of the West African summer monsoon in summer 2006 in the region of Niger/Mali. J. Geophys. Res., 114, D09108, doi:10.1029/2008JD0011159.

Dunkerton, T.J., Delisi, D.P., 1985. Climatology of the equatorial lower stratosphere. Journal of the Atmospheric Sciences 42,376-396.

Eldridge, R. H., 1957: A synoptic study of West African disturbance lines. Quart. J. Roy. Meteor. Soc., 83, 303-314.

Fontain, B., and S. Janicot, 1992: Wind-field coherence and its variations over West Africa. J. Climate, $5,512-524$.

Grist, J.P., Nicholson, E., 2001. A study of the dynamic factors influencing the rain fall variability in the West African Sahel. Journal of Climate 14, 1337-1359.

Grist, J.P., Nicholson, S.E., Barcilon, A.I., 2002. Easterly waves over Africa. Part II: observed and modelled contrasts between wet and dry years. MonthlyWeatherReview130,212-225.

G. S. Meena \& S. D. Patil (2011) Variation of total column ozone along the monsoon trough region over north India, International Journal of Remote Sensing, 32:9, 2581-2590, DOI: 10.1080/01431161003698435.

llesanmi, O. O., 1971: An empirical formulation of an ITD rainfall model for the tropics: A case study of Nigeria. J. Appl. Meteor., 10, 882-891. 
Ilori, O.W., Ajayi, V.O., 2020. Change detection and trend analysis of future temperature and rainfall over west Africa. Earth Syst. Environ. 4 (3), 493-512. https://doi.org/10.1007/s41748-020-00174-6.

Jain, S.L., Kulkarni, P.S., Ghude, S.D., Polade, S.D., Arya, B.C. and Dubey, P.K. (2008) Trend Analysis of Total Column Ozone over New Delhi, India. MAPAN. Journal Metrology Society of India, 23, 6369.

Kalita, G., Pathak, B., Bhuyan, P.K. and Bhuyan, K. (2011) Impact of Zonal Wind on Latitudinal Variation of Total Columnar Ozone over the Indian Peninsula. International Journal of Remote Sensing, 32, 9509-9520. https://doi.org/10.1080/01431161.2011.564221

Kendall, 1975. Rank Correlation Methods, 4th edn. Charles Griffin, San Francisco, CA,p. 8.

Khan, N., et al., 2020. Spatiotemporal changes in precipitation extremes in the arid province of Pakistan with removal of the influence of natural climate variability. Theor.Appl.Climatol. 142 (3-4), 14471462. https://doi.org/10.1007/s00704-020-03389-9.

Kulkarni, P.S., Ghude, D.S., Jain, S.L., Arya, B.C. and Dubey, P.K. (2011) Tropospheric Ozone Variability Over the Indian Coastline and Adjacent Land and Sea. International Journal of Remote Sensing, 32,1545-1559. https://doi.org/10.1080/01431160903571825

Lamb, P. J., 1978a: Case studies of tropical Atlantic surface circulation patterns during recent subSaharan weather anomalies: 1967 and 1968. Mon. Wea. Rev., 106, 482-491.

Lamb, P.J., 1978b: Large-scale tropical Atlantic surface circulation patterns associated with SubSaharan weather anomalies. Tellus, 30, 240-251.

Lélé MI and Lamb PJ (2010). Variability of the Intertropical Front (ITF) and rainfall over the West African Sudan-Sahel zone. Journal of Climate, vol. 23, no. 14, pp. 3984-4004.

Nicholson, S. E., 1980: The nature of rainfall fluctuations in subtropical West Africa. Mon. Wea. Rev., $108,473-487$.

Nicholson, S.E., 2008: The intensity, location and structure of the tropical rain belt over West Africa as factors in Interannual variability. International Journal of climatology, 28 (13): 1775-1785.

Nicholson, S.E., 2009: A revised picture of the structure of the "monsoon" and land ITCZ over West Africa. Climate Dynamics, 32(7-8): 1155-1171.

Nishanth, T., Praseed, K.M., Satheesh Kumar, M.K. and Valsaraj, K.T. (2014) Influence of Ozone Precursors and PM10 on the Variation of Surface O3 over Kannur, India. Atmospheric Research, 138, 112-124. https://doi.org/10.1016/j.atmosres.2013.10.022

Odumodu, L.O., 1983. Rainfall distribution, variability and probability in plateau-state, Nigeria. Journal of Climatology 3, 385-393.

Ogunjobi K.O, Ajayi V.O, Balogun I.A., 2007. Long-term trend analysis of tropospheric total column ozone in Africa. Research Journal of Applied Science2,280-284. 
Olaniran, O.J., 1987. A study of the seasonal-variation of rain-days of different categories in Nigeria in relation to the miller station types for tropical continents. Theoretical and Applied Climatology 38,198-209

Olsson L., 1983. Desertification or Climate? Investigation Regarding the Relationship Between Land Degradation and Climate in the Central Sudan, University of Lund, Dept. of Physical Geography, Sweden, pp.1-35.

Oluleye A, Okogbue EC. Analysis of temporal and spatial variability of total column ozone over West Africa using daily TOMS measurements. Atmospheric Pollution Research. 2013; 4:387-397.

Oluleye A, Ogunjobi KO. The relationship of Nigerian rainfall to global teleconnections and sea surface temperature Journal of Meteorology and Climate Science.2009; 8:71-83.

Omotosho, J.B., 1988.Spatial variation of rainfall in Nigeria during the 'little dry season'. Atmospheric Research 22,137-147.

Omotosho JA and Abiodun BJ (2007). A numerical study of moisture build-up and rainfall over West Africa. Meteorological Applications, 14(3):209-225.

Omotosho, J.B., 2008. Pre-rainy season moisture build-up and storm precipitation delivery in the West African Sahel. International Journal ofClimatology28,937-946.

Pandey, R., \& Vyas, B. (2004). Study of total column ozone, precipitable water content and aerosol optical depth at Udaipur, a tropical station. Current Science, 86(2), 305-309. Retrieved March 5, 2021, from http://www.jstor.org/stable/24107872

Peyrillé $P$ and Lafore JP (2007). An idealized two-dimensional framework to study the West African monsoon. Part II: Largescale advection and the diurnal cycle. J. Atmos. Sci., 64, 2783-2803, doi:10.1175/JAS4052.1.

Resmi, C.T., Nishanth, T., Satheesh Kumar, M.K., Balachandramohan, M. and Valsaraj, K.T. (2020) Long Term Variation of Air Quality Influenced by Surface Ozone in a Coastal Site in India: Association with Synoptic Meteorological Conditions with Model Simulations. Atmosphere, 11, 193.https://doi.org/10.3390/atmos11020193

Solomon, S., 1999. Stratospheric ozone depletion: a review of concepts and history. Reviews of Geophysics 37,275-316.

Stolarski, R.S., Bloomfield, P., Mcpeters, R.D., Herman, J.R., 1991. Total ozone trends deduced from Nimbus 7 TOMS data. Geophysical ResearchLetters18,1015-1018.

Sultan B and Janicot S (2000). Abrupt shift of the ITCZ over West Africa and intra-seasonal variability. Geophysical Research Letters, vol. 27, no. 20, pp. 3353-3356.

Sultan B and Janicot S (2003). The West African monsoon dynamics. Part II: the "preonset" and "onset" of the summer monsoon. Journal of Climate 16: 3389-3406.

Sultan B, Janicot S, and Diedhiou A (2003). The West African Monsoon dynamics. Part I: Documentation of intra seasonal variability. Journal of Climate, 16 (21), 3389-3406. 
613 Toihir, A.M., Portafaix, T., Sivakumar, V., Bencherif, H., Pazmino, A. and Begue, N. (2018) Variability and $614 \quad$ Trend in Ozone over the Southern Tropics and Subtropics. Annales Geophysicae, 36, 381-404. $615 \quad$ https://doi.org/10.5194/angeo-36-381-2018

616 World Meteorological Organization,1985. Atmospheric ozone: assessment of our understanding of the 617 processes controlling its present distribution and change. Its Global Ozone Research and $618 \quad$ Monitoring Project, Report 1985 16, 1095.

619 World Meteorological Organization, Scientific Assessment of Ozone Depletion: 2018, Global Ozone 620 Research and Monitoring Project - Report No. 58, 588 pp., Geneva, Switzerland, 2018.

621 Xue Y., H. Juang, W.-P. Li, S. Prince, R. DeFries, Y. Jiao and R. Vasic, 2004, Role of land surface processes in 622 monsoon development: East Asia and West Africa, J. Geophys. Res.,109, 623 doi :10.1029/2003JD003,556. 